\title{
Protective mechanisms of medicinal plants targeting hepatic stellate cell activation and extracellular matrix deposition in liver fibrosis
}

\author{
Florent Duval', Jorge E Moreno-Cuevas ${ }^{1}$, María Teresa González-Garza' ${ }^{1}$, Carlos Rodríguez-Montalvo² \\ and Delia Elva Cruz-Vega ${ }^{1 *}$
}

\begin{abstract}
During chronic liver injury, hepatic stellate cells (HSC) are activated and proliferate, which causes excessive extracellular matrix (ECM) deposition, leading to scar formation and fibrosis. Medicinal plants are gaining popularity as antifibrotic agents, and are often safe, cost-effective, and versatile. This review aims to describe the protective role and mechanisms of medicinal plants in the inhibition of HSC activation and ECM deposition during the pathogenesis of liver fibrosis. A systematic literature review on the anti-fibrotic mechanisms of hepatoprotective plants was performed in PubMed, which yielded articles about twelve relevant plants. Many of these plants act via disruption of the transforming growth factor beta 1 signaling pathway, possibly through reduction in oxidative stress. This reduction could explain the inhibition of HSC activation and reduction in ECM deposition. Medicinal plants could be a source of anti-liver fibrosis compounds.
\end{abstract}

\section{Introduction}

Liver fibrosis is caused by inappropriate tissue repair via connective tissue deposition, which results from chronic liver injuries, including those from alcohol, chronic viral hepatitis, autoimmune diseases, parasites, metabolic diseases, and toxins or other drugs [1]. When fibrosis is not controlled, it can progress into cirrhosis. Cirrhosis was previously considered to be irreversible, but some studies suggest that fibrosis and cirrhosis could be reversible [2].

Liver fibrosis is a public health problem that results in significant morbidity and mortality [3]. Hundreds of thousands of people worldwide suffer from cirrhosis, partially because of the obesity pandemic combined with the high incidence of alcohol abuse and viral hepatitis [4]. Chronic viral hepatitis (B and C), alcoholic liver disease, and nonalcoholic fatty liver disease are the three most common causes of liver cirrhosis [5]. The prevalence of chronic liver diseases is predicted to increase, partially owing to the rising prevalence of obesity and metabolic syndrome, especially in developed countries [6].

\footnotetext{
* Correspondence: cruzvegade@gmail.com

${ }^{1}$ Cell Therapy Department, School of Medicine, Tecnológico de Monterrey, Monterrey NL CP 63710, Mexico

Full list of author information is available at the end of the article
}

The pathogenesis of liver fibrosis is complex and varies among different kinds of hepatic injuries. Usually after acute liver damage, parenchymal cells are regenerated to replace the necrotic and apoptotic cells. This regenerative process is associated with an inflammatory response and a limited deposition of extracellular matrix (ECM). When the liver is subjected to chronic injury, the regenerative response fails and hepatocytes are replaced with abundant ECM, which is mainly composed of collagen types I, III, and IV; fibronectin; elastin; laminin; and proteoglycans [7]. Hepatic stellate cells (HSC) are the main source of ECM [8].

There is no standard treatment for liver fibrosis [7], but a reduction in liver injury events, such as cessation of alcohol intake or successful viral hepatitis treatment can control fibrosis. Nevertheless, these actions are often insufficient to avoid eventual progression to cirrhosis in the vast majority of patients [9]. Although important advances have been made in understanding the pathogenesis of hepatic fibrosis over the past 20 years, efficient antifibrotic drugs have yet to be developed. There are two ways by which medicinal plants and their bioactive compounds and extracts could reduce liver fibrosis: via 
inhibition of HSC activation and via reduction of ECM deposition (Figure 1). Liver fibrosis treatment should take into account the versatility of its pathogenesis and should act upon all pathways involved, beginning with HSC activation and ECM deposition.

Medicinal plants are often safe, cost-effective, and versatile, and are therefore popular potential antifibrotic agents. This review aims to describe the role of some hepatoprotective plants in the inhibition of HSC activation and ECM deposition in the pathogenesis of liver fibrosis. These plants include: Curcuma longa, Silybum marianum, Ginkgo biloba, Salvia miltiorrhiza, Glycyrrhiza glabra, Scutellaria baicalensis, Bupleurum falcatum, Phyllanthus species, Berberis aristata, Ginseng species, Andrographis paniculata, and Coffea species.

\section{Literature inclusion criteria}

The 12 plant species were selected because of their known hepatoprotective activities. A three-step progressive searching method was applied using PubMed. In each of the steps, only pertinent articles were selected. First, a global search on the liver activity of each plant species was undertaken using the keywords "liver" and "plant species name". The antifibrotic activities were classified under two different pathways: inhibition of HSC activation and suppression of ECM deposition. Bioactive compounds and extracts from every reviewed species were selected. Second, a more advanced search was performed using the terms "liver fibrosis" and "plant species name or bioactive extract name or bioactive compound name". Finally, a search on the antifibrotic mechanisms of each species was performed using the terms "hepatic stellate cells activation", "extracellular matrix", "collagen", and "plant species name or bioactive extract name or bioactive compound name".

\section{Inhibition of hepatic stellate cell activation}

\section{Role of hepatic stellate cell activation in the pathogenesis}

\section{of liver fibrosis}

HSC activation, which includes initiation and perpetuation, is an early event in liver fibrogenesis. The activation of HSCs converts normal, quiescent vitamin A-rich cells into myofibroblast-like cells characterized by proliferation, chemotaxis, fibrogenesis, contractility, matrix degradation, retinoid loss, and white blood cell chemoattractant/cytokine release [10-14].

HSCs are initiated when gene expression and phenotype changes render the quiescent cells responsive to other cytokines and stimuli $[10,12]$. Several paracrine stimuli from damaged hepatocytes and other neighboring cell types, such as Kupffer cells, platelets, sinusoidal endothelium, and immune cells initiate the activation of HSCs [15]. Transforming growth factor beta 1 (TGF- $\beta 1$ ), plateletderived growth factor (PDGF), and epidermal growth factor (EGF) mediate platelet stimuli $[15,16]$. By producing fibronectin and activating latent TGF- $\beta 1$, injured endothelial cells provoke HSC activation. Kupffer cells are important sources of paracrine stimuli for HSCs because they express TGF- $\beta 1$, transforming growth factor alpha (TGF- $\alpha$ ), reactive oxygen species, and lipid peroxides. These Kupffer cell paracrines lead to matrix synthesis, cell proliferation, and the release of retinoids [15] and matrix metalloproteinase (MMP)-9 [17] for collagen synthesis through the activation of latent TGF- $\beta 1$ [18]. Kupffer cells also inhibit fibrogenesis via the production of anti-inflammatory interleukin-10 and nitric oxide (NO), which decrease collagen synthesis, increase collagenase production, and reduce cell proliferation and contractility [15]. All these stimuli trigger important changes in the composition of ECM, especially an increase in type I and III fibril-forming collagens and fibronectin [10]. This

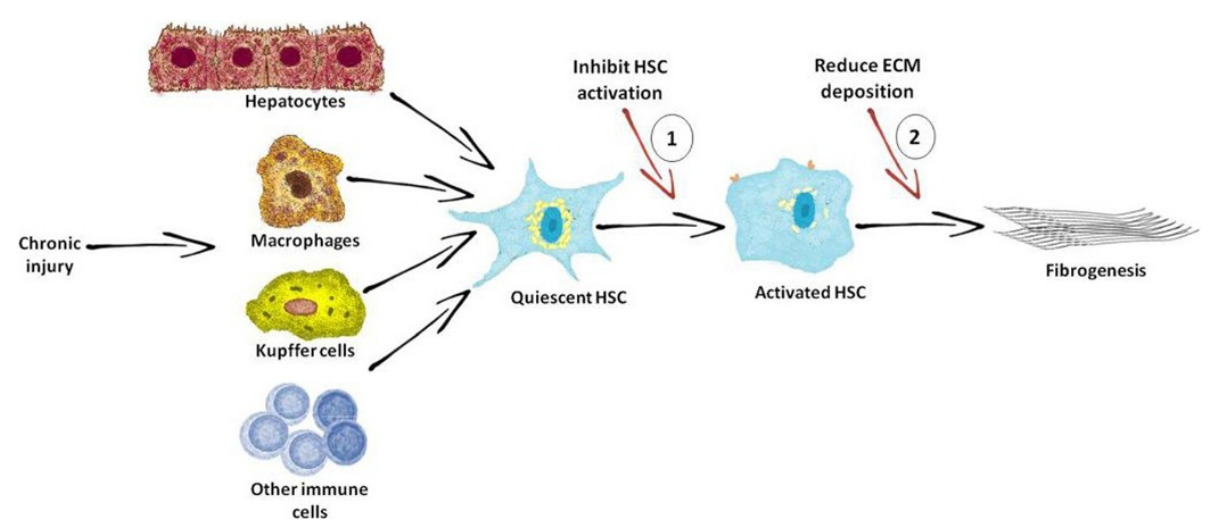

Figure 1 Antifibrotic medicinal plants targeting HSC activation and ECM deposition. HSC: hepatic stellate cells, ECM: extracellular matrix, 1: C. longsa, S. marianum, G. biloba, S. miltiorrhiza, G. glabra, S. baicalensis, B. falcatum, Phyllanthus species, B. aristata, Ginseng species, A. paniculata, and Coffea species. 2: C. longa, S. marianum, G. biloba, S. miltiorrhiza, G. glabra, S. baicalensis, B. falcatum, Phyllanthus species, B. aristata, Ginseng species, and Coffea species. 
compositional transformation of the matrix induces new fibrogenic stimuli, which further exacerbate fibrosis [12].

During HSC activation, regulatory pathways like epigenetic regulation of nuclear factor kappa $\mathrm{B}(\mathrm{NF}-\mathrm{kB})$ and reduction in peroxisome proliferator-activated receptor gamma (PPAR $\gamma$ ) expression modulate the expression of many genes, such as type I collagen ( $\alpha 1$ and $\alpha 2$ chains), smooth muscle $\alpha$-actin, TGF- $\beta 1$, TGF- $\beta$ receptors (T $\beta$ RI and II), MMP-2, and tissue inhibitor of metalloproteinases (TIMP)-1 and -2 [10,12].

Perpetuation of HSC activation results in maintenance of the activated phenotype and therefore the generation of fibrosis [15]. Scars are formed through changes in HSC behavior, like proliferation, fibrogenesis, contractility, chemotaxis, retinoid loss, white blood cell chemoattractant/cytokine release, and matrix degradation [12].

Cell proliferation further promotes liver fibrosis by increasing the number of collagen-producing cells. Several mitogens have been identified to be responsible in liver fibrosis, namely PDGF; vascular endothelial growth factor (VEGF); thrombin and its receptor, EGF; TGF- $\alpha$; keratinocyte growth factor; insulin-like growth factor; proteaseactivated receptor agonists; basic fibroblast growth factor; monocyte chemotactic factor; interleukin-6; connective tissue growth factor (CTGF); endothelin-1; and angiotensin-II $[11,12,19]$.

HSCs migrate towards injured areas in the liver, which increases the fibrogenic response at a specific site via mediation of several chemoattractants, including PDGF, monocyte chemoattractant protein-1 (MCP-1), and chemokine receptor CXCR3 $[10,12]$.

Fibrogenesis is defined as increased fibrotic matrix production, especially that of collagen type I [12]. TGF- $\beta 1$, produced by HSCs and other neighboring cell types like Kupffer cells, sinusoidal endothelial cells, bile duct epithelial cells, and hepatocytes [11], is a potent fibrogenic signal [20] as it increases the production of collagen I and other matrix constituents like fibronectin and proteoglycans $[12,21]$. These effects are induced by the interaction between TGF- $\beta 1$ and the membrane receptor complex formed by T $\beta R I$ and T $\beta$ RII, leading to the phosphorylation of intracellular mediators, namely Smad proteins. Smad proteins are divided into three groups: receptoractivated Smad (R-Smad), common-Smad (Co-Smad) and inhibitory-Smad (I-Smad). Phosphoylated R-Smad (Smad1, Smad2, Smad3, Smad5 and Smad8) dissociate from anchoring proteins and associate with $\mathrm{Co}-\mathrm{Smad}$ (Smad4). R-Smad-Co-Smad complexes are transported into the nucleus where they act as transcription factors. This cascade is inhibited by I-Smad (Smad6 and Smad7) [20]. CTGF (through TGF- $\beta$-dependent and -independent pathways), endothelin-1, leptin, and angiotensin II have also been reported as fibrogenic factors for HSCs $[11,22]$.
Stellate cell contractility is associated with portal hypertension and may lead to the collapse and shrunken state of cirrhotic livers [23]. The increased expression of contractile proteins, smooth muscle $\alpha$-actin, and smooth muscle myosins via calcium-dependent and calciumindependent pathways mediate the contractility of HSCs [11]. Endothelin-1, NO, angiotensinogen II, eicosanoids, atrial natriuretic peptide, somatostatin, and carbon monoxide are some of the signals that contribute to the contractile phenotype of HSCs [12]. Because HSCs are so important to fibrogenesis, the inhibition of HSC activation is a possible therapeutic approach to reversing liver fibrosis [1,4]. For instance, PPAR ligands [24], interferon gamma (IFN $\gamma$ ) [25], and antioxidants [26] reduce liver fibrosis by inhibiting TGF- $\beta 1$ expression and therefore HSC activation.

\section{Hepatic stellate cell activation as a target of antifibrotic medicinal plants}

All the reviewed medicinal plants were shown to suppress HSC activation. Since the activation of HSCs occurs via a complex network of signaling pathways, different targets have been investigated to explain the antifibrotic activity (Table 1).

Activation of TGF- $\beta 1 /$ Smad signaling is one of the most important profibrogenic pathways [20]. The disruption of this pathway is a common feature of all of the reviewed antifibrotic plants. Down-regulation of the expression of TGF- $\beta 1$ and its receptors, T $\beta R I$ and II, and modulation of its mediators Smad 2, 3, and 7 has been observed via curcumin $[28,30,32,34,37,38]$ and compounds from $S$. miltiorrhiza [49,66,70,75-78,83,88-91,98], G. glabra [102,103] and Coffea species [120-128]. Several mechanisms have been identified for the inhibition of TGF- $\beta 1$ signaling via curcumin, like PPARY activation and antioxidation. Curcumin inhibits NF-кB [27], leptin [39], advanced glycation end-product (AGE) [33], low-density lipoprotein (LDL) [40,41], and insulin [42] mediated HSC activation by stimulating PPAR $\gamma$ activity and inducing de novo synthesis of glutathione [27,33,39-42]. Inhibition of NF- $\mathrm{kB}$ and stimulation of PPARy activities are also observed in G. biloba extract [56,57], 18 $\alpha$ glycyrrhizin [101], glycyrrhetinic acid [104], and baicalin [107]. Salianic acid B and salvianolic acid B inhibited p38 mitogen-activated protein kinases $[88,90,94,99,100]$ and extracellular signal-regulated kinases (ERK) signaling $[46,90,92,94,96,98,100]$ by blocking phosphorylation of mitogen-activated protein kinase kinase 3/6, inhibiting expression of myocyte enhancer factor-2 [94], and suppressing phosphorylation of mitogen-activated protein kinase kinase [96,100], in activated HSCs. Further, salvianolic acid B reduced hepatic fibrosis by disrupting angiotensin II signaling via down-regulation of angiotensin II receptor type 1, ERK, and c-Jun phosphorylation [98]. Andrographolide from A. paniculata decreased the 
Table 1 Inhibitory mechanisms of hepatic stellate cell activation via medicinal plants

\begin{tabular}{|c|c|c|}
\hline Medicinal plants & Bioactive compounds/extracts & Targeted fibrogenic pathways \\
\hline C. longa [27-46] & Curcumin & 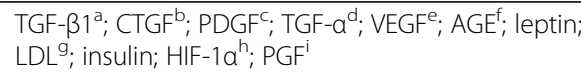 \\
\hline S. marianum [47-54] & Silymarin & TGF- $\beta 1^{\mathrm{a}} ; \mathrm{CTGF}^{\mathrm{b}}$ \\
\hline G. biloba $[55-60]$ & G. biloba extract, EGb761 & TGF- $\beta 1^{\text {a }}$; $C T G F^{\text {b }}$; PAF'; endothelin-1 \\
\hline S. miltiorrhiza $[46,49,61-100]$ & $\begin{array}{l}\text { Water extract of } S \text {. miltiorrhiza; salvianolic acid } A \text {; } \\
\text { salvianolic acid } B \text {; magnesium lithospermate } B \text {; } \\
\text { tanshinone IIA; IH764-3 }\end{array}$ & $\begin{array}{l}\text { TGF- } \beta 1^{\mathrm{a}} ; \mathrm{CTGF}^{\mathrm{b}} ; \mathrm{PDGF}^{\mathrm{c}} ; \mathrm{MCP}^{\mathrm{k}}{ }^{\mathrm{k}} \text {; endothelin-1; } \\
\text { angiotensin II }\end{array}$ \\
\hline G. glabra [101-104] & Glycyrrhizin; 18a-glycyrrhizin; glycyrrhizic acid & TGF- $\beta 1^{a}$ \\
\hline S. baicalensis [105-107] & Baicalin & TGF- $\beta 1^{\mathrm{a}}$ \\
\hline B. falcatum $[32,108,109]$ & Saikosaponin-A; saikosaponin-D & $T G F-\beta 1^{a}$ \\
\hline Phyllanthus species $[110,111]$ & $\begin{array}{l}\text { Ethanol extract of } P \text {. rheedii Wight; ethanol } \\
\text { extract of } P \text {. niruri }\end{array}$ & TGF- $\beta 1^{\mathrm{a}}$ \\
\hline B. aristata $[112-114]$ & Berberine & TGF- $\beta 1^{a}$ \\
\hline P. notoginseng $[105,115-118]$ & $\begin{array}{l}\text { Ginsenoside } \mathrm{Rg} 1 \text {; ginsenoside } \mathrm{Rb} 1 \text {; P. notoginseng } \\
\text { saponins; } 25-\mathrm{OCH}_{3}-\mathrm{PPD}\end{array}$ & TGF- $\beta 1^{a} ;$ PDGF ${ }^{c}$ \\
\hline A. paniculata [119] & Andrographolide & TGF- $\beta 1^{a}$ \\
\hline Coffea species [120-130] & $\begin{array}{l}\text { Caffeine; 1,7-dimethylxanthine; theophylline; } \\
\text { theobromine }\end{array}$ & TGF- $\beta 1^{\mathrm{a}} ; \mathrm{CTGF}^{\mathrm{b}} ; \mathrm{VEGF}^{\mathrm{e}} ; \mathrm{PDGF}^{\mathrm{c}}$ \\
\hline
\end{tabular}

${ }^{a}$ Transforming growth factor beta $1,{ }^{b}$ connective tissue growth factor, ${ }^{c}$ platelet derived growth factor, ${ }^{d}$ transforming growth factor alpha, ${ }^{e}$ vascular endothelial growth factor, ${ }^{\mathrm{f}}$ advance glycation end-product, ${ }^{9}$ low-density lipoprotein, ${ }^{\text {h }}$ hypoxia-inducible factor-1a, ${ }^{\mathrm{i}}$ placental growth factor, ${ }^{\mathrm{j}}$ platelet activate factor, ${ }^{\mathrm{k}}$ monocyte chemotactic protein-1.

hepatic level of cannabinoid receptor $1 \mathrm{via}$ inactivation of c-Jun N-terminal kinases and the ERK phosphorylation cascade [119].

HSC proliferation is mediated by different proteins, including PDGF, CTGF, VEGF, and TGF- $\alpha$ through various signal molecules, such as ERK and focal adhesion kinase (FAK) [12]. Some plant extracts target these growth factors and their respective signaling pathways to reduce the proliferative response of HSCs. CTGF is inhibited by curcumin [34,36], silymarin [54], G. biloba extract [59], Salvia extract $[49,76]$, and caffeine [120,128-130] via inhibition of TGF- $\beta$ signaling. Moreover, curcumin was shown to reduce the promoter activity of CTGF and suppress its gene expression by reducing NF- $\mathrm{kB}$ activity [36]. NF- $\mathrm{kB}$ was inhibited by suppression of ERK activity and suppression of Toll like receptor-4 gene expression via PPAR $\gamma$ activation [36].

PDGF and its receptor PDGF- $\beta$ R were found to be down-regulated by curcumin [35,37], salvianolic acid A [63] and B [92], coffee [123], and ginsenoside Rg1 [116]. Ginsenoside Rg1 down-regulated the expression of PDGF- $\beta R$ by reducing NF-kB activity [116]. Different bioactive compounds from $S$. miltiorrhiza reduced HSC proliferation. The monomer IH764-3 inhibited HSC proliferation by down-regulating FAK and ERK expression $[64,65,80]$, while salvianolic acid B attenuated PDGFinduced c-Jun N-terminal kinases, p38, and protein kinase C delta phosphorylations [95].

VEGF and its receptors were suppressed by curcumin [45] and coffee [122], which could also explain their amelioration of angiogenesis in the fibrotic liver. Additionally, curcumin reduced TGF- $\alpha$ levels [43].

Cyclins, and cyclin inhibitors, are essential proteins for the control of the cell cycle, and potential therapeutic targets for inhibiting HSC proliferation. The cyclin D1 gene was down-regulated by curcumin through PPAR $\gamma$ activation [30]. Inhibition of HSC proliferation by salvianolic acid $\mathrm{A}$ was mediated by the induction of cell cycle inhibitory proteins p21 and p27, down-regulation of cyclins D1 and E, and suppression of protein kinase B phosphorylation [63].

Medicinal plants also regulate the contraction of HSCs. For example, salvianolic acid B lowered portal pressure and attenuated the contraction of HSC by inhibiting the Ras homolog family member A signaling pathway [97] and decreasing the HSC free calcium ion concentration [93].

\section{Reduction in extracellular matrix deposition Role of extracellular matrix deposition in the pathogenesis of liver fibrosis}

Liver fibrosis is a dynamic process in which the equilibrium between ECM synthesis and degradation is impaired [11]. HSCs, neutrophils, and macrophages are the main cellular contributors to ECM degradation [1], while HSCs, portal myofibroblasts, bone-marrowderived cells, and the epithelial-mesenchymal transition are responsible for ECM synthesis [14]. All these cells involve several molecular effectors such as matrix proteins, MMPs and TIMPs. 
During fibrogenesis, several ECM proteins, especially collagens type I, III, and IV; proteoglycans; laminin; and fibronectin are over-expressed by activated HSCs and other cells, which results in pathological scar formation [131]. Accumulation of ECM not only depends on upregulation of ECM production, but also on MMP-TIMP expression $[132,133]$. In the early phases of liver injury, HSCs transiently express MMP-3 and MMP-13, which is a matrix-degrading phenotype. In the later stages of liver injury, the inhibition of fibrillar liver collagen degradation prevails over ECM synthesis, as evidenced by increased TIMP-1 expression, which leads to a decrease in collagen degradation by MMP-1 and MMP-13 [133]. TIMP-1 was found to protect HSCs from apoptosis [134]. Regulation of the plasminogen activation system, including enhanced production of the urokinase-plasminogen activator (uPA) and uPA receptor and modulation of plasminogen activator inhibitor type 1 (PAI-1), is another method by which HSCs regulate the ECM [135-137]. Macrophages also take part in matrix breakdown $[9,138]$, since macrophages produce MMPs, like MMP-13 $[139,140]$ and MMP-9 [141,142] through the mitogenactivated protein kinase and NF-kB pathways [143].

The dynamic process of matrix degradation and synthesis could be a therapeutic target to reversing liver fibrosis and restoring normal liver architecture $[4,11,144]$. Indeed, MMP-8 cloned into an adenoviral vector reversed fibrosis in cirrhotic animal livers [145]. In vivo reduction of liver fibrosis has also been observed with similar therapeutic approaches involving MMP-1 [146], TIMP-1 scavengers [147], and uPA [148].

\section{Extracellular matrix deposition as a target of antifibrotic medicinal plants}

All of the reviewed medicinal plants, except A. paniculata, were shown to reduce ECM deposition. Plant compound targets include multiple components of the ECM, such as collagen species, laminin, and fibronectin, as well as MMPs, TIMPs, and the plasminogen activation system (Table 2).

Table 2 Inhibitory mechanisms of extracellular matrix deposition via medicinal plants

\begin{tabular}{|c|c|c|c|c|c|}
\hline \multirow[t]{2}{*}{ Medicinal plants } & \multirow[t]{2}{*}{ Bioactive compounds/extracts } & \multicolumn{4}{|c|}{ Mechanisms of reduction in ECM deposition } \\
\hline & & $\overline{\downarrow E C M^{\mathrm{a}} \text { proteins }}$ & $\uparrow M_{M P s^{b}}$ & $\downarrow$ TIMPs $^{\mathrm{c}}$ & $\begin{array}{l}\text { Plasminogen } \\
\text { activation system }\end{array}$ \\
\hline $\begin{array}{l}\text { C. longa } \\
{[6,30,32,34,36,37,42-44,46,149-159]}\end{array}$ & Curcumin & $\begin{array}{l}\text { Collagen type I; collagen } \\
\text { type III; fibronectin; } \\
\text { hyaluronic acid; laminin }\end{array}$ & $\begin{array}{l}\text { MMP-2; } \\
\text { MMP-9; } \\
\text { MMP-13; } \\
\text { MMP-7 }\end{array}$ & $\begin{array}{l}\text { TIMP-1; } \\
\text { TIMP-2 }\end{array}$ & - \\
\hline S. marianum $[47,48,50,51,160-165]$ & Silymarin; silibinin (silybin) & $\begin{array}{l}\text { Collagen type I; collagen } \\
\text { type III }\end{array}$ & - & $\begin{array}{l}\text { TIMP-1; } \\
\text { TIMP-2 }\end{array}$ & - \\
\hline G. biloba [55-59,166-169] & G. biloba extract; EGb761 & $\begin{array}{l}\text { Collagen type I; collagen } \\
\text { type III; laminin; hyaluronic } \\
\text { acid; collagen type IV }\end{array}$ & MMP-1 & TIMP-1 & - \\
\hline $\begin{array}{l}\text { S. miltiorrhiza } \\
{[46,49,65,66,75-91,94,96,98,99,170-179]}\end{array}$ & $\begin{array}{l}\text { Salvianolic acid A; salvianolic acid B; } \\
\text { salvianic acid A; salianic acid B; } \\
\text { IH764-3; magnesium; lithospermate B; } \\
\text { tanshinone IIA; SMND-309 }\end{array}$ & $\begin{array}{l}\text { Collagen type I; collagen } \\
\text { type III; hyaluronic acid; } \\
\text { collagen type IV; laminin }\end{array}$ & MMP-13 & TIMP-1 & $\downarrow P A I-1^{d} ; \uparrow \mathrm{PA}^{\mathrm{e}}$ \\
\hline G. glabra $[102-104,180,181]$ & $\begin{array}{l}\text { Glycyrrhizin; glycyrrhetinic acid; } \\
\text { glycyrrhizic acid }\end{array}$ & $\begin{array}{l}\text { Collagen type I; collagen } \\
\text { type III }\end{array}$ & MMP-9 & - & - \\
\hline S. baicalensis $[105,106]$ & Baicalin & $\begin{array}{l}\text { Collagen type I; collagen } \\
\text { type III; hyaluronic acid } \\
\text { collagen type IV }\end{array}$ & - & TIMP-1 & - \\
\hline B. falcatum $[32,108,182]$ & Saikosaponin A; saikosaponin D & $\begin{array}{l}\text { Collagen type I; hyaluronic } \\
\text { acid; collagen type IV; } \\
\text { laminin }\end{array}$ & - & - & - \\
\hline Phyllanthus species $[111,183]$ & $\begin{array}{l}\text { P. amarus extract; ethanol extract } \\
\text { of } P \text {. niruri }\end{array}$ & Collagen type I & MMPs & TIMPS & - \\
\hline B. aristata [114] & berberine & _- & MMP-2 & _- & - \\
\hline $\begin{array}{l}\text { P. notoginseng } \\
{[105,115,117,118,184,185]}\end{array}$ & $\begin{array}{l}\text { P. notoginseng saponins; ginsenoside } \\
\mathrm{Rb} 1 \text {; red ginseng extract; } 25-\mathrm{OCH}_{3}-\mathrm{PPD}\end{array}$ & $\begin{array}{l}\text { Collagen type I; collagen } \\
\text { type III; hyaluronic acid; } \\
\text { collagen type IV }\end{array}$ & MMP-13 & TIMP-1 & $\downarrow P A I-I^{d}$ \\
\hline \multirow{2}{*}{$\begin{array}{l}\text { Coffea species } \\
{[122,124-126,128,186-189]}\end{array}$} & \multirow{2}{*}{$\begin{array}{l}\text { Decaffeinated coffee; normal coffee; } \\
\text { 1,7-dimethylxanthine; caffeine; } \\
\text { chlorogenic acid }\end{array}$} & Collagen type I & \multirow[t]{2}{*}{ - } & \multirow[t]{2}{*}{-} & \multirow[t]{2}{*}{-} \\
\hline & & Collagen type III & & & \\
\hline
\end{tabular}


Curcumin, silymarin, silybin, silibinin, G. biloba extracts like GbE761, salvianolic acids A and B, salianic acid B, $S$. miltiorrhiza extracts, magnesium lithospermate $\mathrm{B}$, tanshinone IIA, monomer IH764-3, glycyrrhizin, glycyrrhetinic acid, glycyrrhizic acid, baicalin, saikosaponin A and D, $P$. amarus extracts, berberine, $P$. notoginseng saponins, ginsenoside $\mathrm{Rb} 1$, red ginseng extract, conventional and decaffeinated coffee, 1,7-dimethylxanthine, caffeine, and chlorogenic acid, reduced hepatic collagen content by down-regulating hepatic expression of type I and III collagen and/or decreasing the serum levels of type III procollagen and type IV collagen. Fibronectin expression was reduced by curcumin [37]. Serum levels of laminin and hyaluronic acid were lowered by curcumin, $G$. biloba extracts like GbE761, salvianolic acid B, SMND309, baicalin, saikosaponin $\mathrm{D}$, and $P$. notoginseng saponins. Expression of MMPs, like MMP-1, -2, -7, -9, and -13 , were enhanced by curcumin $[30,43,154,157]$, G. biloba extract [166], S. miltiorrhiza [66,77], salianic acid B [90], monomer IH764-3 [178], glycyrrhizin [181], baicalin [105], berberine [114], and P. notoginseng saponins [185], which stimulate the degradation of collagen deposits. However, MMPs have been observed to be downregulated after treatment with curcumin [158], silymarin [50,51], S. miltiorrhiza [172], salvianolic acid B [175], ethanol extract of $P$. niruri [111], ginsenoside Rb1 [117], conventional and decaffeinated coffee, and caffeine $[125,126,128]$. Tissue remodeling induced by MMPs progresses liver fibrosis, so reducing MMP expression could be an antifibrotic strategy. Moreover, curcumin, silymarin, G. biloba extract, S. miltiorrhiza, monomer IH764-3, baicalin, $P$. amarus extract, $P$. notoginseng saponins, and ginsenoside $\mathrm{Rb} 1$ inhibited the expression of TIMP-1 and -2 . Salvianic acid A (danshensu) and red ginseng extract down-regulated the expression of PAI-1 [173,184], while salvianic acid A up-regulated uPA expression [173].

Since ECM proteins, MMPs, and TIMPS are overexpressed when HSCs are activated, the inhibition of HSC activation and proliferation is the main method by which plants can suppress ECM deposition. The antifibrotic mechanism is mainly the result of down-regulating the TGF- $\beta 1 /$ Smad signaling pathway.

\section{Highlights}

Inhibition of HSC activation and subsequent ECM deposition via medicinal plants is the result of TGF- $\beta 1 /$ Smad signaling disruption. The down-regulation of T $\beta R I$ and II and modulation of Smads suggests a common mechanism upstream to the pathway affected by the plants. Since oxidative stress is involved in the activation of HSCs, antioxidative properties could be the common mechanism by which the plants inhibit HSC activation and ECM deposition.
The antifibrotic properties of medicinal plants have mainly been observed in liver fibrosis models in vitro and in vivo. Clinical studies are sparse and mainly recruited chronic hepatitis $\mathrm{B}$ and $\mathrm{C}$ patients to assess the hepatoprotective effects of medicinal plants. Silymarin, glycyrrhizin, and S. miltiorrhiza have been somewhat successfully tested. Glycyrrhizin treatment induced a decrease in alanine transaminase and maintenance and improvement of necroinflammation in chronic hepatitis $\mathrm{C}$ nonresponders, and those patients unlikely to respond to interferon therapy when they receive at least three injections weekly over the course of 4,22 , or 52 weeks [190-193]. Since glycyrrhizin had no effect on hepatitis C RNA [190], investigation of the hepatoprotective mechanisms, such as inhibition of HSC activation and ECM deposition, is necessary.

Salvia injection and salvianolic acid B, have been tested in patients infected with hepatitis B. Salvianolic acid B, administrated over 6 months, reversed liver fibrosis and inflammation more effectively than IFN $\gamma$ in patients with hepatitis $\mathrm{B}$, as suggested by significant improvement in serum hyaluronic acid, laminin, type IV collagen, and procollagen III peptide as compared with the IFN $\gamma$ group [194]. The same results, as well as decreased levels of alanine transaminase and aspartate transaminase were observed in fibrotic and cirrhotic patients infected with hepatitis B virus who were treated with Salvia injections over 45 [195] or 60 days [196]. However, another study on chronic hepatitis B patients treated with S. miltiorrhiza injection showed improvements only in symptoms, physical signs, and liver functions, not antifibrotic effects. Therefore, additional clinical studies are required to understand the effect of S. miltiorrhiza injection on liver fibrosis [197].

Clinical studies on silymarin administration for the treatment of hepatitis $\mathrm{C}$ were inconclusive. Silymarin has antiviral activity and has been associated with reduced progression from fibrosis to cirrhosis in advanced hepatitis C patients [198]. However, it has low oral bioavailability at $0.73 \%$ in rat plasma [199-201] and has not always been associated with hepatic improvement. For example, it was not effective in patients with chronic viral hepatitis $C$ infection that who also unsuccessfully treated with interferon-based therapy [202].

Besides HSC activation and ECM deposition, other events like oxidative stress, inflammation, and immune responses are involved in the fibrogenic response $[10,11,13,14]$. These pathways are potential targets that could help reduce hepatic fibrosis. Nevertheless, several medicinal plants have been shown to inhibit HSC activation and ECM deposition during liver fibrosis.

\section{Abbreviations}

AGE: Advanced glycation end-product; Co-Smad: Common-Smad; CTGF: Connective tissue growth factor; ECM: Extracellular matrix; 
EGF: Epidermal growth factor; ERK: Extracellular signal-regulated kinases; FAK: Focal adhesion kinase; HSC: Hepatic stellate cells; IFNy: Interferon gamma; I-Smad: Inhibitory-Smad; LDL: Low-density lipoprotein; MCP-1: Monocyte chemoattractant protein-1; MMP: Matrix metalloproteinase; NF-kB: Nuclear factor kappa B; NO: Nitric oxide; PAl-1: Plasminogen activator inhibitor type 1; PDGF: Platelet-derived growth factor; PDGF-BR: Platelet-derived growth factor beta; PPARY: Peroxisome proliferator-activated receptor gamma; RSmad: Receptor-activated Smad; TGF-a: Transforming growth factor alpha; TGF- $\beta 1$ : Transforming growth factor beta 1; TRRII: Transforming growth factor beta 1 receptor II; TRRI: Transforming growth factor beta 1 receptor l; TIMP: Tissue inhibitor of metalloproteinases; UPA: urokinase-plasminogen activator; VEGF: Vascular endothelial growth factor.

\section{Competing interests}

The authors declare that they have no competing interests.

\section{Authors' contributions}

FD and DEC conceived and designed the study. FD and DEC analyzed the data. FD, DEC, JEM, MTG, and CR wrote the manuscript. All authors read and approved the final manuscript.

\section{Acknowledgements}

Supported by: CONACYT for the PhD student grant. This work was partially funded by endowments from Instituto Tecnológico de Estudios Superiores de Monterrey (cat-134) and the Zambrano-Hellion Foundation.

\section{Author details}

${ }^{1}$ Cell Therapy Department, School of Medicine, Tecnológico de Monterrey, Monterrey NL CP 63710, Mexico. ${ }^{2}$ Centro de Enfermedades

Hepáticas-Digestivas y Nutrición, HSJ, Monterrey, NL, Mexico.

Received: 16 April 2014 Accepted: 26 November 2014

Published online: 24 December 2014

\section{References}

1. Mormone E, George J, Nieto N: Molecular pathogenesis of hepatic fibrosis and current therapeutic approaches. Chem Biol Interact 2011, 193:225-231.

2. Ellis EL, Mann DA: Clinical evidence for the regression of liver fibrosis. J Hepatol 2012, 56:1171-1180.

3. Sánchez-Valle V, Chávez-Tapia NC, Uribe M, Méndez-Sánchez N: Role of oxidative stress and molecular changes in liver fibrosis: a review. Curr Med Chem 2012, 19:4850-4860

4. Friedman SL: Liver fibrosis - from bench to bedside. J Hepatol 2003, 38:S38-S53.

5. Poynard T, Mathurin P, Lai CL, Guyader D, Poupon R, Tainturier MH, Myers RP, Muntenau M, Ratziu V, Vogel A, Capron F, Chedid A, Bedossa P, PANFIBROSIS Group: A comparison of fibrosis progression in chronic liver diseases. J Hepatol 2003, 38:257-265.

6. Lim YS, Kim WR: The global impact of hepatic fibrosis and end-stage liver disease. Clin Liver Dis 2008, 12:733-746.

7. Bataller R, Brenner DA: Liver fibrosis. J Clin Invest 2005, 115:209-218.

8. Reeves HL, Friedman SL: Activation of hepatic stellate cells-a key issue in liver fibrosis. Front Biosci 2002, 7:d808-d826.

9. Henderson NC, Iredale JP: Liver fibrosis: cellular mechanisms of progression and resolution. Clin Sci (Lond) 2007, 112:265-280.

10. Friedman SL: Mechanisms of hepatic fibrogenesis. Gastroenterology 2008, 134:1655-1669.

11. Rockey DC: Translating and understanding of the pathogenesis of hepatic fibrosis to novel therapies. Clin Gastroenterol Hepatol 2013, 11:224-231.

12. Friedman SL: Hepatic stellate cells: Protean, multifunctional and enigmatic cells of the liver. Physiol Rev 2008, 88:125-172

13. Lee UE, Friedman SL: Mechanisms of hepatic fibrogenesis. Best Pract Res Clin Gastroenterol 2011, 25:195-206.

14. Jiao J, Friedman SL, Aloman C: Hepatic fibrosis. Curr Opin Gastroenterol 2009, 25:223-229.

15. Friedman SL: Hepatic fibrosis - role of hepatic stellate cell activation. Med Gen Med 2002, 4:27.

16. Bachem MG, Melchior R, Gressner AM: The role of thrombocytes in liver fibrogenesis: effects of platelet lysate and thrombocyte-derived growth factors on the mitogenic activity and glycosaminoglycan synthesis of cultures rat liver fat storing cells. J Clin Chem Clin Biochem 1989, 27:555-565.

17. Winwood PJ, Schuppan D, Iredale JP, Kawser CA, Docherty AJ, Arthur MJ: Kupffer cell-derived 95-kd type IV collagenase/gelatinase B: characterization and expression in cultured cells. Hepatology 1995, 22:304-315.

18. Yu Q, Stamenkovic I: Cell surface-localized matrix metalloproteinase-9 proteolytically activates TGF-beta and promotes tumor invasion and angiogenesis. Genes Dev 2000, 14:163-176.

19. Pinzani M, Marra F: Cytokine receptors and signaling in hepatic stellate cells. Semin Liver Dis 2001, 21:397-416.

20. Mauviel A: Transforming growth factor- $\beta$ : a key mediator of fibrosis. Meth Mol Med 2005, 117:69-80

21. George J, Roulot D, Koteliansky VE, Bissell DM: In vivo inhibition of rat stellate cell activation by soluble transforming growth factor beta type II receptor: a potential new therapy for hepatic fibrosis. Proc Natl Aca SCi USA 1999, 96:12719-12724.

22. Grotendorst GR: Connective tissue growth factor: a mediator of TGF-beta action on fibroblasts. Cytokine Growth Factor Rev 1997, 8:171-179.

23. Rockey DC: Vascular mediators in the injured liver. Hepatology 2003, $37: 4-12$

24. Attia YM, Elalkamy EF, Hammam OA, Mahmoud SS, El-Khatib AS: Telmisartan, an AT1 receptor blocker and a PPAR gamma activator, alleviates liver fibrosis induced experimentally by Schistosoma mansoni infection. Parasit Vectors 2013, 6:199.

25. Baroni GS, D'Ambrosio L, Curto P, Casini A, Mancini R, Jezequel AM, Benedetti A: Interferon gamma decreases hepatic stellate cell activation and extracellular matrix deposition in rat liver fibrosis. Hepatology 1996, 23:1189-1199

26. Calleja MA, Vieites JM, Montero-Meterdez T, Torres MI, Faus MJ, Gil A, Suárez A: The antioxidant effect of $\beta$-caryophyllene protects rat liver from carbon tetrachloride-induced fibrosis by inhibiting hepatic stellate cell activation. Br J Nutr 2013, 109:394-401.

27. Xu J, Fu Y, Chen A: Activation of peroxisome proliferator-activated receptor-gamma contributes to the inhibitory effects of curcumin on rat hepatic stellate cell growth. Am J Physiol Gastrointest Liver Physiol 2003, 285:G20-G30.

28. Zheng $\mathrm{S}$, Chen A: Activation of PPARgamma is required for curcumin to induce apoptosis and to inhibit the expression of extracellular matrix genes in hepatic stellate cells in vitro. Biochem J 2004, 384:149-157.

29. He YJ, Shu JC, Lü X, Fang L, Sheng Y: Prophylactic effect of curcumin on hepatic fibrosis and its relationship with activated hepatic stellate cells. Zhonghua Gan Zang Bing Za Zhi 2006, 14:337-340.

30. Cheng Y, Ping J, Xu LM: Effects of curcumin on peroxisome proliferatoractivated receptor gamma expression and nuclear translocation/ redistribution in culture-activated rat hepatic stellate cells. Chin Med J 2007, 120:794-801

31. Shu JC, He YJ, Lv X, Ye GR, Wang LX: Curcumin prevents liver fibrosis by inducing apoptosis and suppressing activation of hepatic stellate cells. J Nat Med 2009, 63:415-420.

32. Wu SJ, Tam KW, Tsai YH, Chang CC, Chao JC: Curcumin and saikosaponin a inhibit chemical-induced liver inflammation and fibrosis in rats. Am J Chin Med 2010, 38:99-111.

33. Lin J, Tang Y, Kang Q, Feng Y, Chen A: Curcumin inhibits gene expression of receptor for advanced glycation end-products (RAGE) in hepatic stellate cells in vitro by elevating PPAR $\gamma$ activity and attenuating oxidative stress. Br J Pharmacol 2012, 166:2212-2227.

34. Yao QY, Xu BL, Wang JY, Liu HC, Zhang SC, Tu CT: Inhibition by curcumin of multiples sites of the transforming growth factor-beta 1 signalling pathway ameliorates the progression of liver fibrosis induced by carbon tetrachloride in rats. BMC Complement Altern Med 2012, 12:156.

35. Park SD, Jung JH, Lee HW, Kwon YM, Chung KH, Kim MG, Kim CH: Zedoariae rhizoma and curcumin inhibits platelet-derived growth factor-induced proliferation of human hepatic myofibroblasts. Int Immunopharmacol 2005, 5:555-569.

36. Chen $\mathrm{A}$, Zheng $\mathrm{S}$ : Curcumin inhibits connective tissue growth factor gene expression in activated hepatic stellate cells in vitro by blocking NF-KB and ERK signalling. Br J Pharmacol 2008, 153:557-567.

37. Fu Y, Zheng S, Lin J, Ryerse J, Chen A: Curcumin protects the rat liver from $\mathrm{CCl} 4$-caused injury and fibrogenesis by attenuating oxidative stress and suppressing inflammation. Mol Pharmacol 2008, 73:399-409. 
38. Reyes-Gordillo K, Segovia J, Shibayama M, Tsutsumi V, Vergara T, Moreno MG, Muriel P: Curcumin prevents and reverses cirrhosis induced by bile duct obstruction or $\mathrm{CCl} 4$ in rats: role of TGF-beta modulation and oxidative stress. Fundam Clin Pharmacol 2008, 22:417-427.

39. Tang Y, Zheng S, Chen A: Curcumin eliminates leptin's effects on hepatic stellate cell activation via interrupting leptin signalin. Endocrinology 2009, 150:3011-3020.

40. Kang $\mathrm{Q}$, Chen A: Curcumin suppresses expression of low-density lipoprotein $(\mathrm{LDL})$ receptor, leading to the inhibition of $\mathrm{LDL}$-induced activation of hepatic stellate cells. Br J Pharmacol 2009, 157:1354-1367.

41. Kang Q, Chen A: Curcumin eliminates oxidized LDL roles in activating hepatic stellate ells by suppressing gene expression of lectin-like oxidized LDL receptor-1. Lab Invest 2009, 89:1275-1290.

42. Lin J, Zheng S, Chen A: Curcumin attenuates the effects of insulin on stimulating hepatic stellate cell activation by interrupting insulin signaling and attenuating oxidative stress. Lab Invest 2009, 89:1397-1409.

43. Morsy MA, Abdalla AM, Mahmoud AM, Abdelwahab SA, Mahmoud ME: Protective effects of curcumin, a-lipoic acid, and $\mathrm{N}$-acetylcysteine against carbon tetrachloride-induced liver fibrosis in rats. J Physiol Biochem 2012, 68:29-35.

44. Tu CT, Yao QY, Xu BL, Wang JY, Zhou CH, Zhang SC: Protective effects of curcumin against hepatic fibrosis induced by carbon tetrachloride: modulation of high-mobility group box 1, Toll-like receptor 4 and 2 expression. Food Chem Toxicol 2012, 50:3343-3351.

45. Yao Q, Lin Y, Li X, Shen X, Wang J, Tu C: Curcumin ameliorates intrahepatic angiogenesis and capillarization of the sinusoids in carbon tetrachloride-induced rat liver fibrosis. Toxicol Lett 2013, 222:72-82.

46. Cheng Y, Ping J, Liu C, Tan YZ, Chen GF: Study on effects of extracts from Salvia Miltiorrhiza and Curcuma Longa in inhibiting phosphorylated extracellular signal regulated kinase expression in rat's hepatic stellate cells. Chin J Integr Med 2006, 12:207-211.

47. Jia JD, Bauer M, Cho JJ, Ruehl M, Milani S, Boigk G, Riecken EO, Schuppan D: Antifibrotic effect of silymarin in rat secondary biliary fibrosis is mediated by downregulation of procollagen alpha1(I) and TIMP-1. J Hepatol 2001, 35:392-398.

48. Jeong DH, Lee GP, Jeong WI, Do SH, Yang HJ, Yuan DW, Park HY, Kim KJ, Jeong KS: Alterations of mast cells and TGF-beta1 on the silymarin treatment for CCI(4)-induced hepatic fibrosis. World J Gastroenterol 2005, 11:1141-1148.

49. Hsu YC, Lin YL, Chiu YT, Shiao MS, Lee CY, Huang YT: Antifibrotic effects of Salvia miltiorrhiza on dimethylnitrosamine-intoxicated rats. J Biomed Sci 2005, 12:185-195.

50. Chen IS, Chen YC, Chou CH, Chuang RF, Sheen LY, Chiu CH: Hepatoprotection of silymarin against thioacetamide-induced chronic liver fibrosis. J Sci Food Agric 2012, 92:1441-1447.

51. El-Lakkany NM, Hammam OA, El-Maadawy WH, Badawy AA, Ain-Shoka AA, Ebeid FA: Anti-inflammatory/anti-fibrotic effects of the hepatoprotective silymarin and the schistosomicide praziquantel against Schistosoma mansoni-induced liver fibrosis. Parasit Vectors 2012, 5:9.

52. Li CC, Hsiang CY, Wu SL, Ho TY: Identification of novel mechanisms of silymarin on the carbon tetrachloride-induced liver fibrosis in mice by nuclear factor-KB bioluminescent imaging-guided transcriptomic analysis. Food Chem Toxicol 2012, 50:1568-1575.

53. Kim M, Yang SG, Kim JM, Lee JW, Kim YS, Lee Jl: Silymarin suppresses hepatic stellate cell activation in a dietary rat model of non-alcoholic steatohepatitis: analysis of isolated hepatic stellate cells. Int J Mol Med 2012, 30:473-479.

54. Tzeng Jl, Chen MF, Chung HH, Cheng JT: Silymarin decreases connective tissue growth factor to improve liver fibrosis in rats treated with carbon tetrachloride. Phytother Res 2013, 27:1023-1028.

55. Ding J, Yu J, Wang C, Hu W, Li D, Luo Y, Luo H, Yu H: Ginkgo biloba extract alleviates liver fibrosis induced by CCl in rats. Liver Int 2005, 25:1224-1232

56. Liu SQ, Yu JP, He L, Yu HG, Luo HS: Effects of nuclear factor kappaB and transforming growth factor beta1 in the anti-liver fibrosis process using Ginkgo biloba extract. Zhonghua Gan Zang Bing Za Zhi 2005, 13:903-907.

57. Liu SQ, Yu JP, Chen HL, Luo HS, Chen SM, Yu HG: Therapeutic effects and molecular mechanisms of Ginkgo biloba extract on liver fibrosis in rats. Am J Chin Med 2006, 34:99-114.
58. He SX, Luo JY, Wang YP, Wang YL, Fu H, Xu JL, Zhao G, Liu EQ: Effects of extract from Ginkgo biloba on carbon tetrachloride-induced liver injury in rats. World J Gastroenterol 2006, 12:3924-3928.

59. Zhang C, Zhu Y, Wan J, Xu H, Shi H, Lu X: Effects of Ginkgo biloba extract on cell proliferation, cytokines and extracellular matrix of hepatic stellate cells. Liver Int 2006, 26:1283-1290.

60. Zhang CF, Zhang CQ, Zhu YH, Wang J, Xu HW, Ren WH: Ginkgo biloba extract EGb 761 alleviates hepatic fibrosis and sinusoidal microcirculation disturbance in patients with chronic hepatitis $B$. Gastroen Res 2008, 1:20-28.

61. Zhang $X L$, Liu L, Jiang HQ: Salvia miltiorrhiza monomer $\mathbb{I H 7 6 4 - 3}$ induces hepatic stellate cell apoptosis via caspase-3 activation. World J Gastroenterol 2002, 8:515-519.

62. Chor SY, Hui AY, To KF, Chan KK, Go YY, Chan HL, Leung WK, Sung JJ: Anti-proliferative and pro-apoptotic effects of herbal medicine on hepatic stellate cell. J Ethnopharmacol 2005, 100:180-186.

63. Lin YL, Lee TF, Huang YJ, Huang YT: Antiproliferative effect of salvianolic acid A on rat hepatic stellate cells. J Pharm Pharmacol 2006, 58:933-939.

64. Fang SM, Li CS, An JY, Dun ZN, Yao DM, Liu L, Zhang XL: The role of extracellular signal-regulated kinase in induction of apoptosis with salvia miltiorrhiza monomer IH764-3 in hepatic stellate cells. Zhongguo Ying Yong Sheng Li Xue Za Zhi 2011, 27:402-406.

65. Liu L, Wei J, Huo X, Fang S, Yao D, Gao J, Jiang H, Zhang X: The Salvia miltiorrhiza monomer IH764-3 induces apoptosis of hepatic stellate cells in vivo in a bile duct ligation-induced model of liver fibrosis. Mol Med Rep 2012, 6:1231-1238.

66. Wasser S, Ho JM, Ang HK, Tan CE: Salvia miltiorrhiza reduces experimentally-induced hepatic fibrosis in rats. J Hepatol 1998, 29:760-771.

67. Shang Q, Zhang D, Guan W: The inhibitory effect in vitro of salvia miltiorrhiza and tetramethyl pyrazine on the growth of fibroblasts. Zhongguo Xiu Fu Chong Jian Wai Ke Za Zhi 1998, 12:321-324.

68. Shang $Q$, Zhang D, Guan W: The influence of salvia miltiorrhiza and tetramethyl pyrazine on DNA content of cicatricial fibroblasts and its cellular cycle. Zhongguo Xiu Fu Chong Jian Wai Ke Za Zhi 1998, 12:325-328.

69. Nan JX, Park EJ, Kang HC, Park PH, Kim JY, Sohn DH: Anti-fibrotic effects of a hot-water extract from Salvia miltiorrhiza roots on liver fibrosis induced by biliary obstruction in rats. J Pharm Pharmacol 2001, 53:197-204.

70. Wang YM, Wei FK, Liu M: Effect of Salvia miltiorrhiza on autocrining growth factor by fibroblasts cultured in vitro. Zhongguo Xiu Fu Chong Jian Wai Ke Za Zhi 2002, 16:408-410.

71. Lay IS, Chiu JH, Shiao MS, Lui WY, Wu CW: Crude extract of Salvia miltiorrhiza and salvianolic acid $B$ enhance in vitro angiogenesis in murine SVR endothelial cell line. Planta Med 2003, 69:26-32.

72. Wang JM, Yao XX, Li XT, Yang SL, Su Z: Effects of Radix Salviae Miltiorrhizae on $\mathrm{Ca} 2+$ in hepatic stellate cells. Sichuan Da Xue Xue Bao Yi Xue Ban 2005, 36:221-224.

73. Yao XX, LV T: Effects of pharmacological serum from normal and liver fibrotic rats on HSCs. World J Gastroenterol 2005, 11:2444-2449.

74. LV T, Yao XX: Comparison of protocatechuic aldchyde in Radix Salvia miltiorrhiza and corresponding pharmacological sera from normal and fibrotic rats by high performance liquid chromatography. World J Gastroenterol 2006, 12:2195-2200.

75. Paik YH, Yoon YJ, Lee HC, Jung MK, Kang SH, Chung SI, Kim JK, Cho JY, Lee KS, Han KH: Antifibrotic effects of magnesium lithospermate $B$ on hepatic stellate cells and thioacetamide-induced cirrhotic rats. Exp Mol Med 2011, 43:341-349.

76. Sferra R, Vetuschi A, Catitti V, Ammanniti S, Pompili S, Melideo D, Frieri G, Gaudio E, Latella G: Boswellia serrata and Salvia miltiorrhiza extracts reduce DMN-induced hepatic fibrosis in mice by TGF-beta1 downregulation. Eur Rev Med Pharmacol Sci 2012, 16:1484-1498.

77. Zhang Y, Zhang Y, Xie Y, Gao Y, Ma J, Yuan J, Li J, Wang J, Li L, Zhang J, Chu L: Multitargeted inhibition of hepatic fibrosis in chronic iron-overloaded mice by Salvia miltiorrhiza. J Ethnopharmacol 2013, 148:671-681.

78. Sun RF, Liu LX, Zhang HY: Effect of tanshinone II on hepatic fibrosis in mice. Zhongguo Zhong Xi Yi Jie He Za Zhi 2009, 29:1012-1017.

79. Liu J: The effect of IH764-3 on proliferation and function of fibroblasts. Zhongguo Yi Xue Ke Xue Yuan Xue Bao 1993, 15:201-205. 
80. Liu L, Jiang $H Q$, Zhang $X L$ : The effect and mechanism of Salvia miltiorrhiza monomer IH764-3 on proliferation and collagen synthesis of hepatic stellate cells stimulated by $\mathrm{H} 2 \mathrm{O} 2$. Zhongguo Ying Yong Sheng $\mathrm{Li}$ Xue Za Zhi 2003, 19:78-81.

81. Liu J, Hua G, Liu W, Cui Y, Huang H, Zhao S, Chu Y, Yang C, Chen W: The effect of IH764-3 on fibroblast proliferation and function. Chin Med Sci J 1992, 7:142-147.

82. Liu CH, Liu P, Hu YY, Xu LM, Tan YZ, Wang ZN, Liu C: Effects of salvianolic acid-A on rat hepatic stellate cell proliferation and collagen production in culture. Acta Pharmacol Sin 2000, 21:721-726.

83. Liu C, Liu P, Hu Y, Zhu D: Effects of salvianolic acid-B on TGF-beta 1 stimulated hepatic stellate cell activation and its intracellular signaling. Zhonghua Yi Xue Za Zhi 2002, 82:1267-1272.

84. Lin YL, Wu CH, Luo MH, Huang YJ, Wang CN, Shiao MS, Huang YT: In vitro protective effects of salvianolic acid B on primary hepatocytes and hepatic stellate cells. J Ethnopharmacol 2006, 105:215-222.

85. Wang R, Yu XY, Guo ZY, Wang YJ, Wu Y, Yuan YF: Inhibitory effects of salvianolic acid $\mathrm{B}$ on $\mathrm{CCl}(4)$-induced hepatic fibrosis through regulating NF-KB/IkBa signaling. J Ethnopharmacol 2012, 144:592-598.

86. Hu Y, Wang R, Zhang X, Liu C, Liu C, Liu P, Zhu D: Effects of carbon tetrachloride-injured hepatocytes on hepatic stellate cell activation and salvianolic acid A preventive action in vitro. Zhonghua Gan Zang Bing Za Zhi 2000, 8:299-301.

87. Liu CH, Hu YY, Wang XL, Liu P, Xu LM: Effects of salvianolic acid-A on NIH/ 3 T3 fibroblast proliferation, collagen synthesis and gene expression. World J Gastroenterol 2000, 6:361-364.

88. Liu P, Liu CH, Wang HN, Hu YY, Liu CC: Effect of salvianolic acid B on collagen production and mitogen-activated protein kinase activity in rat hepatic stellate cells. Acta Pharmacol Sin 2002, 23:733-738.

89. Zhao JF, Liu CH, Hu YY, Xu LM, Liu P, Liu C: Effect of salvianolic acid B on Smad3 expression in hepatic stellate cells. Hepatobiliary Pancreat Dis Int 2004, 3:102-105.

90. Xue DY, Hong JH, Xu LM: Salianic-acid B inhibits MAPK signaling in activated rat hepatic stellate cells. Zhonghua Gan Zang Bing Za Zhi 2004, $12: 471-474$

91. Wang XN, Hu YY, Liu CH, Liu P, Zhu DY: Effects of salvianolic acid B on expressions of TGF-beta1 and its receptors in liver of rats with dimethylnitrosamine-induced hepatic fibrosis. Zhong Xi Yi Jie He Xue Bao 2005, 3:286-289

92. Xue DY, Hong $J H$, Xu LM: Effects of salvianolic acid B on signal transduction induced by transforming growth factor-beta1 and platelet-derived growth factor- BB in hepatic stellate cells of rats. Zhongguo Zhong Xi Yi Jie He Za Zhi 2006, 26:439-442.

93. Zhang J, Zhang WW, Xu LM: Effect and mechanism of salvianolic-acid B on inhibiting endothelin-1-induced contraction of human hepatic stellate cells. Zhongguo Zhong Xi Yi Jie He Za Zhi 2009, 29:60-64.

94. Lv Z, Song Y, Xue D, Zhang W, Cheng Y, Xu L: Effect of salvianolic-acid B on inhibiting MAPK signaling induced by transforming growth factor- $\beta 1$ in activated rat hepatic stellate cells. J Ethnopharmacol 2010, 132:384-392.

95. Tsai MK, Lin YL, Huang YT: Differential inhibitory effects of salvianolic acids on activation of rat hepatic stellate cells by platelet-derived growth factor. Planta Med 2011, 77:1495-1503.

96. Song YF, Lü ZG, Xu LM: Salvianolic acid B inhibits ERK signal transduction pathway activated by transforming growth factor- $\beta 1$ in rat hepatic stellate cells. Zhong Xi Yi Jie He Xue Bao 2012, 10:454-461.

97. Xu H, Zhou Y, Lu C, Ping J, Xu LM: Salvianolic acid B lowers portal pressure in cirrhotic rats and attenuates contraction of rat hepatic stellate cells by inhibiting RhoA signaling pathway. Lab Invest 2012, 92:1738-1748.

98. Li S, Wang L, Yan X, Wang Q, Tao Y, Li J, Peng Y, Liu P, Liu C: Salvianolic acid $B$ attenuates rat hepatic fibrosis via downregulating angiotensin II signaling. Evid Based Complement Alternat Med 2012, 2012:160726.

99. Song YF, LV ZG, Xu LM: Effects of salvianolic-acid B on the p38MAPK signaling pathway and its transcriptional factor induced by transforming growth factor b1 in activated rat hepatic stellate cells. Zhonghua Gan Zang Bing Za Zhi 2012, 20:902-907.

100. Lv Z, Xu L: Salvianolic Acid B inhibits ERK and p38 MAPK signaling in TGF- $\beta 1$-stimulated human hepatic stellate lell line (LX-2) via distinct pathways. Evid Based Complement Altern Med 2012, 2012:960128.
101. Qu Y, Chen WH, Zong L, Xu MY, Lu LG: 18a-Glycyrrhizin induces apoptosis and suppresses activation of rat hepatic stellate cells. Med Sci Monit 2012, 18:BR24-BR32

102. Dong L, Sun JY, Fang GT, Jiang LD, Wang JY: Effects of glycyrrhizin on TGFbeta1 stimulated hepatic stellate cell signaling transduction. Zhonghua Gan Zang Bing Za Zhi 2005, 13:828-831.

103. Moro T, Shimoyama Y, Kushida M, Hong YY, Nakao S, Higashiyama R, Sugioka $Y$, Inoue $H$, Okazaki I, Inagaki $Y$ : Glycyrrhizin and its metabolite inhibit Smad3-mediated type I collagen gene transcription and suppress experimental murine liver fibrosis. Life Sci 2008, 83:531-539.

104. Wang JY, Zhang QS, Guo JS, Hu MY: Effects of glycyrrhetinic acid on collagen metabolism of hepatic stellate cells at different stages of liver fibrosis in rats. World J Gastroentero/ 2001, 7:115-119.

105. Li X, Peng XD, Zhang WL, Dai LL: Inhibiting effects of denshensu, baicalin, astragalus and Panax notoginseng saponins on hepatic fibrosis and their possible mechanisms. Zhonghua Gan Zang Bing Za Zhi 2008, 16:193-197.

106. Peng XD, Dai LL, Huang CQ, He CM, Chen LJ: Correlation between anti-fibrotic effect of baicalin and serum cytokines in rat hepatic fibrosis. World J Gastroenterol 2009, 15:4720-4725.

107. Qiao H, Han H, Hong D, Ren Z, Chen Y, Zhou C: Protective effects of baicalin on carbon tetrachloride induced liver injury by activating PPARY and inhibiting TGF $\beta 1$. Pharm Biol 2011, 49:38-45.

108. Fan J, Li X, Li P, Li N, Wang T, Shen H, Siow Y, Choy P, Gong Y: Saikosaponin-d attenuates the development of liver fibrosis by preventing hepatocyte injury. Biochem Cell Biol 2007, 85:189-195.

109. Wang X, Wang Q, Burczynski FJ, Kong W, Gong Y: Saikosaponin A of Bupleurum chinense (Chaihu) elevates bone morphogenetic protein 4 (BMP-4) during hepatic stellate cell activation. Phytomedicine 2013, 20:1330-1335.

110. Suresh V, Asha W: Preventive effect of ethanol extract of Phyllanthus rheedii Wight. on D-galactosamine induced hepatic damage in Wistar rats. J Ethnopharmacol 2008, 116:447-453.

111. Amin ZA, Alshawsh MA, Kassim M, Ali HM, Abdulla MA: Gene expression profiling reveals underlying molecular mechanism of hepatoprotective effect of Phyllanthus niruri on thioacetamide-induced hepatotoxicity in Sprague Dawley rats. BMC Complement Altern Med 2013, 13:160.

112. Zhang BJ, Xu D, Guo Y, Ping J, Chen LB, Wang H: Protection by and anti-oxidant mechanism of berberine against rat liver fibrosis induced by multiple hepatotoxic factors. Clin Exp Pharmacol Physiol 2008, 35:303-309.

113. Sun X, Zhang X, Hu H, Lu Y, Chen J, Yasuda K, Wang H: Berberine inhibits hepatic stellate cell proliferation and prevents experimental liver fibrosis. Biol Pharm Bull 2009, 32:1533-1537.

114. Domitrović $R$, Jakovac $H$, Marchesi W, Blažeković B: Resolution of liver fibrosis by isoquinoline alkaloid berberine in $\mathrm{CCl}_{4}$-intoxicated mice is mediated by suppression of oxidative stress and upregulation of MMP-2 expression. J Med Food 2013, 16:518-528.

115. Wu YL, Wan $Y$, Jin XJ, OuYang BQ, Bai T, Zhao YQ, Nan JX: 25-OCH3-PPD induces the apoptosis of activated $\mathrm{t}-\mathrm{HSC} / \mathrm{Cl}-6$ cells via c-FLIP-mediated NF-KB activation. Chem Biol Interact 2011, 194:106-112.

116. Geng J, Peng W, Huang Y, Fan H, Li S: Ginsenoside-Rg1 from Panax notoginseng prevents hepatic fibrosis induced by thioacetamide in rats. Eur J Pharmacol 2010, 634:162-169.

117. Lo YT, Tsai YH, Wu SJ, Chen JR, Chao JC: Ginsenoside Rb1 inhibits cell activation and liver fibrosis in rat hepatic stellate cells. J Med Food 2011, 14:1135-1143

118. Peng XD, Dai LL, Huang CQ, He CM, Yang B, Chen LJ: Relationship between anti-fibrotic effect of Panax notoginseng saponins and serum cytokines in rat hepatic fibrosis. Biochem Biophys Res Commun 2009, 388:31-34.

119. Lee TY, Lee KC, Chang HH: Modulation of the cannabinoid receptors by andrographolide attenuates hepatic apoptosis following bile duct ligation in rats with fibrosis. Apoptosis 2010, 15:904-914.

120. Gressner OA, Lahme B, Rehbein K, Siluschek M, Weiskirchen R, Gressner AM: Pharmacological application of caffeine inhibits TGF-beta-stimulated connective tissue growth factor expression in hepatocytes via PPARgamma and SMAD2/3-dependent pathways. J Hepatol 2008, 49:758-767.

121. Gressner OA: About coffee, cappuccino and connective tissue growth factor-Or how to protect your liver? Environ Toxicol Pharmacol 2009, 28:1-10. 
122. Shi $H$, Dong $L$, Zhang $Y$, Bai $Y$, Zhao J, Zhang L: Protective effect of a coffee preparation (Nescafe pure) against carbon tetrachloride-induced liver fibrosis in rats. Clin Nutr 2010, 29:399-405.

123. Shin JW, Wang JH, Kang JK, Son CG: Experimental evidence for the protective effects of coffee against liver fibrosis in SD rats. J Sci Food Agric 2010, 90:450-455

124. Klemmer I, Yagi S, Gressner OA: Oral application of 1,7-dimethylxanthine (paraxanthine) attenuates the formation of experimental cholestatic liver fibrosis. Hepatol Res 2011, 41:1094-1109.

125. Furtado KS, Prado MG, Aguiar E, Silva MA, Dias MC, Rivelli DP, Rodriques MA Barbisan LF: Coffee and caffeine protect against liver injury induced by thioacetamide in male Wistar rats. Basic Clin Pharmacol Toxicol 2012, 111:339-347.

126. Arauz J, Moreno MG, Cortés-Reynosa P, Salazar EP, Muriel P: Coffee attenuates fibrosis by decreasing the expression of TGF- $\beta$ and CTGF in a murine model of liver damage. J Appl Toxicol 2013, 33:970-979.

127. Shim SG, Jun DW, Kim EK, Saeed WK, Lee KN, Lee HL, Lee OY, Choi HS, Yoon BC: Caffeine attenuates liver fibrosis via defective adhesion of hepatic stellate cells in cirrhotic model. J Gastroenterol Hepatol 2013, 28:1877-1884

128. Arauz J, Zarco N, Segovia J, Shibayama M, Tsutsumi V, Muriel P: Caffeine prevents experimental liver fibrosis by blocking the expression of TGF- $\beta$. Eur J Gastroenterol Hepatol 2013, 26:164-173.

129. Gressner OA, Siluschek M, Lahme B, Gressner AM: Intraperitoneal application of caffeine prevents D-galactosamine-induced hepatic expression of connective tissue growth factor (CTGF/CCN2) in the rat. J Hepatol 2009, 50:1053-1055.

130. Gressner OA, Lahme B, Siluschek M, Gressner AM: Identification of paraxanthine as the most potent caffeine-derived inhibitor of connective tissue growth factor expression in liver parenchymal cells. Liver Int 2009 29:886-897

131. Rockey DC: Current and future anti-fibrotic therapies for chronic liver disease. Clin Liver Dis 2008, 12:939-962.

132. Knittel T, Mehde M, Grundmann A, Saile B, Scharf JG, Ramadori G: Expression of matrix metalloproteinases and their inhibitor during hepatic tissue repair in rat. Histochem Cell Biol 2000, 113:443-453.

133. Benyon RC, Arthur MJ: Extracellular matrix degradation and the role of hepatic stellate cells. Semin Liver Dis 2001, 21:373-384.

134. Murphy FR, Issa R, Zhou X, Ratnarajah S, Nagase H, Arthur MJ, Benyon C, Iredale JP: Inhibition of apoptosis of activated hepatic stellate cells by tissue inhibitor of metalloproteinase- 1 is mediated via effects on matrix metalloproteinase inhibition: implications for reversibility of liver fibrosis. J Biol Chem 2002, 277:11069-11076.

135. Knittel T, Fellmer P, Ramadori G: Gene expression and regulation of plasminogen activator inhibitor type I in hepatic stellate cells of rat liver. Gastroenterology 1996, 111:745-754.

136. Zhang LP, Takahara T, Yata Y, Furui K, Jin B, Kawada N, Watanabe A: Increased expression of plasminogen activator and plasminogen activator inhibitor during liver fibrogenesis of rats: role of stellate cells. J Hepatol 1999, 31:703-711.

137. Fibbi G, Pucci M, Grappone C, Pellegrini G, Salzano R, Casini A, Milani S, Del Rosso M: Functions of the fibrinolytic system in human Ito cells and its control by basic fibroblast and platelet-derived growth factor. Hepatology 1999, 29:868-878.

138. Wynn TA, Barron L: Macrophages: master regulators of inflammation and fibrosis. Semin Liver Dis 2010, 30:245-257.

139. Hironaka K, Sakaida I, Matsumura Y, Kaino S, Miyamoto K, Okita K: Enhanced interstitial collagenase (Matrix metalloproteinase-13) production of Kupffer cell by gadolimium chloride prevents pig serum-induced rat liver fibrosis. Biochem Biophys Res Commun 2000, 267:290-295.

140. Fallowfield JA, Mizuno M, Kendall TJ, Constandinou CM, Benyon RC, Duffield JS, Iredale JP: Scar-associated macrophages are a major source of hepatic matrix metalloproteinase-13 and facilitate the resolution of murine hepatic fibrosis. J Immunol 2007, 178:5288-5295.

141. Friedman SL: Mac the knife? Macrophages: the double-edged sword of hepatic fibrosis. J Clin Invest 2005, 115:29-32.

142. Knittel T, Mehde M, Kobold D, Saile B, Dinter C, Ramadori G: Expression patterns of matrix metalloproteinases and their inhibitors in parenchymal and non-parenchymal cells of rat liver: regulation by TNF-a and TGF- $\beta 1$. J Hepatol 1999, 30:48-60.
143. Huang WC, Sala-Newby GB, Susana A, Johnson JL, Newby AC: Classical macrophage activation up-regulates several matrix metalloproteinase's through mitogen activated protein kinases and nuclear factor-KB. PLOS One 2012, 7:e42507.

144. Fallowfield JA: Therapeutic targets in liver fibrosis. Am J Physiol Gastrointest Liver Physiol 2011, 300:G709-G715.

145. Siller-López F, Sandoval A, Salgado S, Salazar A, Bueno M, Garcia J, Vera J, Gálvez J, Hernández I, Ramos M, Aguilar-Cordova E, Armendariz-Borunda J: Treatment with human metalloproteinase- 8 gene delivery ameliorates experimental rat liver cirrhosis. Gastroenterology 2004, 126:1122-1133.

146. limuro Y, Nishio T, Morimoto T, Nitta Tm Stefanovic B, Choi SK, Brenner DA, Yamaoka Y: Delivery of matrix metalloproteinase-1 attenuates established liver fibrosis in the rat. Gastroenterology 2003, 124:445-458.

147. Roderfeld M, Weiskirchen R, Wagner S, Berres ML, Henkel C, Grötzinger J, Gressner AM, Matern S, Roeb E: Inhibition of hepatic fibrogenesis by matrix metalloproteinase-9 mutants in mice. FASEB J 2006, 20:444-454

148. Bueno M, Salgado S, Beas-Zárate C, Armendariz-Borunda J: Urokinase-type plasminogen activator gene therapy in liver cirrhosis is mediated by collagens gene expression down-regulation and up-regulation of MMPs, HGF and VEGF. J Gene Med 2006, 8:1291-1299.

149. Lin YL, Lin CY, Chi CW, Huang YT: Study on antifibrotic effects of curcumin in rat hepatic stellate cells. Phytother Res 2009, 23:927-932.

150. Kang HC, Nan JX, Park PH, Kin JY, Lee SH, Woo SW, Zhao YZ, Park EJ, Sohn DH: Curcumin inhibits collagen synthesis and hepatic stellate cell activation in-vivo and in-vitro. J Pharm Pharmacol 2002, 54:119-126.

151. Yang $W$, Chen $H$, Jiang $Y$ : Inhibitive effect of curcumin and amiloride on the fibrosis of rat hepatic stellate cells induced by oxidative stress. Zhong Yao Cai 2003, 26:795-798.

152. Zheng $\mathrm{S}$, Chen $\mathrm{A}$ : Curcumin suppresses the expression of extracellular matrix genes in activated hepatic stellate cells by inhibiting gene expression of connective tissue growth factor. Am J Physiol Gastrointest Liver Physiol 2006, 290:G883-G893.

153. Bruck R, Ashkenazi M, Weiss S, Goldiner I, Shapiro H, Aeed H, Genina O, Helpern Z, Pines M: Prevention of liver cirrhosis in rats by curcumin. Liver Int 2007, 27:373-383.

154. Cheng Y, Ping J, Liu C: Effect of curcumin on activity of matrix metalloproteinase 2, 9 and nuclear expression of RelA in rat hepatic stellate cells by activating peroxisome proliferator-activated receptor gamma signal. Zhongguo Zhong Xi Yi Jie He Za Zhi 2007, 27:439-443.

155. Shu JC, Ye GR, Lü X, Fang L, Wu HE, Chen XJ: Therapeutic effects of curcumin treatment on hepatic fibrosis. Zhonghua Gan Zang Bing Za Zhi 2007, 15:753-757.

156. Vizzutti F, Provenzano A, Galastri S, Milani S, Delogu W, Novo E, Caligiuri A, Zamara E, Arena U, Laffi G, Parola M, Pinzani M, Marra F: Curcumin limits the fibrogenic evolution of experimental steatohepatitis. Lab Invest 2010, 90:104-115.

157. Pinlaor S, Prakobwong S, Hiraku Y, Pinlaor P, Laothong U, Yongvanit P: Reduction of periductal fibrosis in liver fluke-infected hamsters after long-term curcumin treatment. Eur J Pharmacol 2010, 638:134-141.

158. Hassan ZK, Al-Olayan EM: Curcumin reorganizes miRNA expression in a mouse model of liver fibrosis. Asian Pac J Canc Prev 2012, 13:5405-5408.

159. Zhang Z, Guo Y, Zhang S, Zhang Y, Wang Y, Ni W, Kong D, Chen W, Zheng $S:$ Curcumin modulates cannabinoid receptors in liver fibrosis in vivo and inhibits extracellular matrix expression in hepatic stellate cells by suppressing cannabinoid receptor type-1 in vitro. Eur J Pharmacol 2013, 721:133-140

160. Boigk G, Stroedter L, Herbst H, Waldschmidt J, Riecken EO, Schuppan D: Silymarin retards collagen accumulation in early and advanced biliary fibrosis secondary to complete bile duct obliteration in rats. Hepatology 1997, 26:643-649.

161. Lieber CS, Leo MA, Cao Q, Ren C, DeCarli LM: Silymarin retards the progression of alcohol-induced hepatic fibrosis in baboons. J Clin Gastroenterol 2003, 37:336-339.

162. Trappoliere M, Caligiuri A, Schmid M, Bertolani C, Failli P, Vizzutti F, Novo E, di Manzano C, Marra F, Loguercio C, Pinzani M: Silybin, a component of sylimarin, exerts anti-inflammatory and anti-fibrogenic effects on human hepatic stellate cells. J Hepatol 2009, 50:1102-1111.

163. Shaker ME, Zalata KR, Mehal WZ, Shiha GE, Ibrahim TM: Comparison of imatinib, nilotinib and silymarin in the treatment of carbon tetrachloride-induced hepatic oxidative stress, injury and fibrosis. Toxicol Appl Pharmacol 2011, 252:165-175 
164. Ezhilarasan D, Karthikeyan S, Vivekanandan P: Ameliorative effect of silibinin against $\mathrm{N}$-nitrosodimethylamine-induced hepatic fibrosis in rats. Environ Toxicol Pharmacol 2012, 34:1004-1013.

165. Lin YL, Hsu YC, Chiu YT, Huang YT: Antifibrotic effects of a herbal combination regimen on hepatic fibrotic rats. Phytother Res 2008, 22:69-76.

166. Luo YJ, Yu JP, Shi ZH, Wang L: Ginkgo biloba extract reverses CCl4-induced liver fibrosis in rats. World J Gastroenterol 2004, 10:1037-1042

167. Li W, Dai QT, Liu ZE: Preliminary study on early fibrosis of chronic hepatitis B treated with Ginkgo biloba Composita. Zhongguo Zhong Xi Yi Jie He Za Zhi 1995, 15:593-595.

168. Sener G, Kabasakal L, Yüksel M, Gedik N, Alican Y: Hepatic fibrosis in biliary-obstructed rats is prevented by Ginkgo biloba treatment. World J Gastroenterol 2005, 11:5444-5449.

169. Huang SZ, Luo YJ, Wang L, Cai KY: Effect of ginkgo biloba extract on livers in aged rats. World J Gastroenterol 2005, 11:132-135.

170. Hu YY, Liu P, Liu C, Xu LM, Liu CH, Zhu DY, Huang MF: Actions of salvianolic acid $\mathrm{A}$ on $\mathrm{CCl} 4$-poisoned liver injury and fibrosis in rats. Zhongguo Yao Li Xue Bao 1997, 18:478-480.

171. Lee TY, Wang GJ, Chiu JH, Lin HC: Long-term administration of Salvia miltiorrhiza ameliorates carbon tetrachloride-induced hepatic fibrosis in rats. J Pharm Pharmacol 2003, 55:1561-1568

172. Oh SH, Cho KH, Yang BS, Roh YK: Natural compounds from Danshen suppress the activity of hepatic stellate cells. Arch Pharm Res 2006, 29:762-767.

173. Zhang L, Wu T, Chen JM, Yang LL, Song HY, Ji G: Danshensu inhibits acetaldehyde-induced proliferation and activation of hepatic stellate cell-T6. Zhong Xi Yi Jie He Xue Bao 2012, 10:1155-1161.

174. Tsai MK, Lin YL, Huang YT: Effects of salvianolic acids on oxidative stress and hepatic fibrosis in rats. Toxicol Appl Pharmacol 2010, 242:155-164.

175. Wang L, Tao Y, Li S, Chen G, Liu C: Effects of salvianolic acid B on lipid peroxidation and metalloproteinase-2 activity in fibrotic liver in rat. Zhongguo Zhong Yao Za Zhi 2010, 35:71-75.

176. Hou J, Tian J, Jiang W, Gao Y, Fu F: Therapeutic effects of SMND-309, a new metabolite of salvianolic acid $B$, on experimental liver fibrosis. Eur J Pharmacol 2011, 650:390-395.

177. Tao YY, Wang QL, Shen L, Fu WW, Liu CH: Salvianolic acid B inhibits hepatic stellate cell activation through transforming growth factor beta-1 signal transduction pathway in vivo and in vitro. Exp Biol Med (Maywood) 2013, 238:1284-1296.

178. Liu L, Jiang HQ, Zhang XL, Zhao DQ: Effect of Salvia miltiorrhiza monomer IH764-3 on MMP-13 and TIMP-1 by downregulating the expression of focal adhesion kinase in hepatic stellate cell stimulated by $\mathrm{H} 2 \mathrm{O} 2$. Zhongguo Ying Yong Sheng Li Xue Za Zhi 2007, 23:482-486.

179. Yang C: Effect of IH764-3 on prolyl hydroxylation in collagen biosynthesis. Zhongguo Yi Xue Ke Xue Yuan Xue Bao 1993, 15:364-368.

180. Guo XL, Liang B, Wang XW, Fan FG, Kin J, Lan R, Yang JH, Wang XC, Jin L, Cao Q: Glycyrrhizic acid attenuates $\mathrm{CCl}_{4}$-induced hepatocyte apoptosis in rats via a p53-mediated pathway. World J Gastroenterol 2013, 19:3781-3791

181. Abe K, Ikeda T, Wake K, Sato T, Sato T, Inoue H: Glycyrrhizin prevents of lipopolysaccharide/D-galactosamine-induced liver injury through down-regulation of matrix metalloproteinase-9 in mice. J Pharm Pharmacol 2008, 60:91-97.

182. He Y, Hu ZF, Li P, Xiao C, Chen YW, Li KM, Guo JZ, Pan L, Xiong JP: Experimental study of saikosaponin-D (SSd) on lipid peroxidation of hepatic fibrosis on rat. Zhongguo Zhong Yao Za Zhi 2008, 33:915-919.

183. Surya Narayanan B, Latha P, Rukkumani R: Protective effects of Phyllanthus amarus on fibrotic markers during alcohol and polyunsaturated fatty acid-induced toxicity. Toxicol Mech Methods 2011, 21:48-52.

184. Ki SH, Yang JH, Ku SK, Kim SC, Kim YW, Cho IJ: Red ginseng extract protects against carbon tetrachloride-induced liver fibrosis. J Ginseng Res 2013, 37:45-53.

185. Jiang H, Xia LZ, Li Y, Li X, Wu J: Effect of Panax notoginseng saponins on expressions of MMP-13 and TIMP-1 in rats with hepatic fibrosis. Zhongguo Zhong Yao Za Zhi 2013, 38:1206-1210.

186. Vitaglione P, Morisco F, Mazzone G, Amoruso DC, Ribecco MT, Romano A, Fogliano V, Caporaso N, D'Argenio G: Coffee reduces liver damage in a rat model of steatohepatitis: the underlying mechanisms and the role of polyphenols and melanoidins. Hepatology 2010, 52:1652-1661.
187. Moreno MG, Chávez E, Aldaba-Muruato LR, Segovia J, Vergara P, Tsutsumi V, Shibayama M, Rivera-Espinoza Y, Muriel P: Coffee prevents $\mathrm{CCl}(4)$-induced liver cirrhosis in the rat. Hepatol Int 2011, 5:857-863.

188. Shi H, Dong L, Bai Y, Zhao J, Zhang Y, Zhang L: Chlorogenic acid against carbon tetrachloride-induced liver fibrosis in rats. Eur J Pharmacol 2009, 623:119-124.

189. Shi H, Dong L, Jiang J, Zhao J, Zhao G, Dang X, Lu X, Jia M: Chlorogenic acid reduces liver inflammation and fibrosis through inhibition of toll-like receptor 4 signaling pathway. Toxicology 2013, 303:107-114.

190. van Rossum TG, Vulto AG, Hop WC, Brouwer JT, Niesters HG, Schalm SW Intravenous glycyrrhizin for the treatment of chronic hepatitis C: a double-blind, randomized, placebo-controlled phasel/II trial. J Gastroenterol Hepatol 1999, 14:1093-1099.

191. van Rossum TG, Vulto AG, Hop WC, Schalm SW: Glycyrrhizin-induced reduction of ALT in European patients with chronic hepatitis C. Am J Gastroenterol 2001, 96:2432-2437.

192. Orlent H, Hansen BE, Willems M, Brouwer JT, Huber R, Kullak-Ublick GA Gerken G, Zeuzem S, Nevens F, Tielemans WC, Zondervan PE, Lagging M, Westin H, Schalm SW: Biochemical and histological effects of 26 weeks of glycyrrhizin treatment in chronic hepatitis C: a randomized phase II trial. J Hepatol 2006, 45:539-546.

193. Manns MP, Wedemeyer H, Singer A, Khomutjanskaja N, Dienes HP, Roskams T, Goldin R, Hehnke U, Inoue H, European SNMC, Study Group: Glycyrrhizin in patients who failed previous interferon alpha-based therapies: biochemical and histological effects after 52 weeks. J Viral Hepat 2012, 19:537-546.

194. Liu P, Hu YY, Liu C, Zhu DY, Xue HM, Xu ZQ, Xu LM, Liu CH, Gu HT, Zhang ZQ Clinical observation of salvianolic acid $B$ in treatment of liver fibrosis in chronic hepatitis B. World J Gastroenterol 2002, 8:679-685.

195. She SF, Huang XZ, Tong GD: Clinical study on treatment of liver fibrosis by different dosages of Salvia injection. Zhongguo Zhong Xi Yi Jie He Za Zhi 2004, 24:17-20.

196. Ye F, Liu Y, Qiu G, Zhao Y, Liu M: Clinical study in treatment of cirrosis by different stages of salvia injection. Zhong Yao Cai 2005, 28:850-854.

197. Jin CX, Yang J, Sun HF: Comparative study of the clinical effects of salvia miltiorrhiza injection and shengmai injection on chronic hepatitis $B$. Zhongguo Zhong Xi Yi Jie He Za Zhi 2006, 26:936-938.

198. Freedman ND, Curto TM, Morishima C, Seeff LB, Goodman ZD, Wright EC, Sinha R, Everhart JE, HALT-C Trial Group: Silymarin use and liver disease progression in the Hepatitis C Antiviral Long-Term Treatment against Cirrhosis. Aliment Pharmacol Ther 2011, 33:127-137.

199. Wu JW, Lin LC, Hung SC, Chi CW, Tsai TH: Analysis of silibinin in rat plasma and bile for hepatobiliary excretion nd oral bioavilbility application. J Pharm Biomed Anal 2007, 45:635-641.

200. Hawke RL, Schrieber SJ, Soule TA, Wen Z, Smith PC, Reddy KR, Wahed AS, Belle SH, Afdhal NH, Navarro VJ, Berman J, Liu QY, Doo E, Fried MW, SyNCH Trial group: Silymarin ascending multiple oral dosing phase I study in noncirrhotic patients with chronic hepatitis C. J Clin Pharmacol 2010, 50:434-449.

201. Schrieber SJ, Hawke RL, Wen Z, Smith PC, Reddy KR, Wahed AS, Belle SH, Afdhal NH, Navarro VJ, Meyers CM, Doo E, Fried MW: Differences in the disposition of silymarin between patients with nonalcoholic fatty liver disease and chronic hepatitis C. Drug Metab Dispos 2011, 39:2182-2190.

202. Fried MW, Navrro VJ, Afdhal N, Belle SH, Wahed AS, Hawke RL, Doo E, Meyers CM, Reddy KR, Silymarin in NASH and C Hepatitis (SyNCH) Study Group: Effect of silymarin (milk thistle) on liver disease in patients with chronic hepatitis $C$ unseccessfully treated with interferin therapy: a randomized controlled trial. JAMA 2012, 308:274-282. 